\title{
Technology for monitoring industrial enterprises by the level of economic security
}

\author{
Elena Karanina, Nataliya Maksimova*, and Vyacheslav Kazantsev \\ Vyatka State University, Moskovskaya St., 36, 610000 Kirov, Russia
}

\begin{abstract}
This article discusses the technology of monitoring industrial enterprises by the level of economic security. The problem of the financial crisis is a global problem. To get out of this state, it is necessary to monitor, review the management system and assess the level of economic security of the enterprise. The state and development of the industrial brunch is very important for the economy. In modern realities, the industrial enterprise is considered as a complex economic system, within which various processes are managed, among which an important place is occupied by innovative development. In the process of monitoring, it is necessary to pay sufficient attention to the target orientation and selection of evaluation indicators. To monitor light industry enterprises by the level of economic security, it is advisable to use economic and statistical methods. In the framework of this research the task is solved by the method of multidimensional statistical comparison. The reference values of the level of economic security have been determined and the rating of industrial enterprises of the North-West region has been determined.
\end{abstract}

\section{Introduction}

Today, the problem of the financial crisis is not only a national problem in Russia, but also has a global scale. In the process of emerging from the global financial crisis and overcoming economic instability, enterprises face many challenges. In this regard, there is an urgent need to monitor, review the management system and assess the level of economic security of the enterprise. The state and development of the industrial sector is very important for the economy as a whole. At all times, industry has been an economic engine. The level of security of the entire society with material goods directly depends on its state [1].

In modern realities, an industrial enterprise is considered as a complex economic system, within which various processes are managed, among which innovative development takes an important place. The efficiency of any enterprise always depends on financial and economic stability, flexibility of management decisions, orientation and possibility of innovative development [2].

Let's consider the concept of monitoring. In a broad sense, monitoring is defined as a complex system of monitoring of any object. In a narrower sense, carrying out of target monitoring at the industrial enterprises is carried out on a voluntary basis and is realized

*Corresponding author: info-mna@yandex.ru 
according to the instruction of the management for definition of a vector of development by means of establishment of the best indicators of development, and also revealing of existing financial, economic and social problems which have developed at the moment of carrying out of research [3]. The result of the monitoring is to determine the rating of enterprises by certain criteria and identify the best ones. Those enterprises, which have shown the highest results, become the standard for the others.

Targeted monitoring can be applied at enterprises within the framework of state programs. Usually this is used to determine the attractiveness of an enterprise for investors [4].

In the process of monitoring, regardless of the industry, it is necessary to pay sufficient attention to the target focus and selection of evaluation indicators. Quantitative evaluation is always a higher priority than qualitative evaluation [5]. In the course of monitoring, a large number of different indicators are analyzed. Some of them are publicly available, while others have limited access.

Targeted monitoring provides an opportunity to optimize the innovation breakthrough in the industry under study - in particular, in the country as a whole [4].

Due to the large number of industry-specific features, it is unfortunately not possible at present to conduct monitoring in a uniform manner. Heads of enterprises make their own decisions about the need to conduct monitoring. It should be noted that information about plans and problems of a competitor's enterprise is a commercial secret, and management decisions cannot be made based on the analysis of undocumented information $[5,6]$.

\section{Materials and methods}

Theoretical and methodological concepts of building a system of indicators of economic security at the regional / business level were considered earlier in the works of authors: E. V. Karanina, D. A. Loginov, K. E. Kartavykh, E. S. Sapozhnikova, O. A. Ryazanova, L. Yurieva, N. Grischuk, A. N. Timin, L. P. Domracheva, M. Bortnikov, M. V. Palkina and others [7 - 17].

To monitor light industry enterprises on the level of economic security, in our opinion, it is advisable to use economic and statistical methods (the method of multivariate statistical comparison).

The analysis of scientific publications and the results of an expert survey of managers and leading specialists of industrial enterprises, as well as calculated indicators, allow us to justify the main indicators and threats to economic security.

So, we can distinguish the following indicators:

$\mathrm{x}_{1}$ - the coefficient of update;

$\mathrm{x}_{2}-$ the coefficient of absolute liquidity;

$\mathrm{x}_{3}$ - - the coefficient of the borrowed and own funds of the enterprise;

$\mathrm{x}_{4}$ - the coefficient of stability of staff;

$\mathrm{x}_{5}$-the coefficient of information armament;

$\mathrm{x}_{6}$ - the coefficient of social benefits in the volume of net profit;

$\mathrm{x}_{7}$ - the coefficient of environmental friendliness of products;

$\mathrm{x}_{8}$ - the coefficient of export and import products;

$\mathrm{X}_{9}$ - the coefficient of the current activity of the enterprise;

$\mathrm{x}_{10}$ - the coefficient of innovation potential;

$\mathrm{x}_{11}$ - the coefficient of educational level of lawyers at the enterprise.

Table 1 shows the initial data for calculations: 
Table 1. Matrix of source data

\begin{tabular}{|l|c|c|c|c|c|c|c|c|c|c|c|}
\hline \multicolumn{1}{|c|}{ Company } & $\mathbf{X}_{\mathbf{1}}$ & $\mathbf{X}_{\mathbf{2}}$ & $\mathbf{X}_{\mathbf{3}}$ & $\mathbf{X}_{\mathbf{4}}$ & $\mathbf{X}_{\mathbf{5}}$ & $\mathbf{X}_{\mathbf{6}}$ & $\mathbf{X}_{\mathbf{7}}$ & $\mathbf{X}_{\mathbf{8}}$ & $\mathbf{X}_{\mathbf{9}}$ & $\mathbf{X}_{\mathbf{1 0}}$ & $\mathbf{X}_{\mathbf{1 1}}$ \\
\hline CJSC "Salyut" & 0,12 & 0,74 & 0,15 & 0,60 & 1,05 & 0,03 & 0,23 & 0,20 & 1,10 & 0,89 & 0,67 \\
\hline $\begin{array}{l}\text { JSC research } \\
\text { and production } \\
\text { enterprise } \\
\text { "ANA" }\end{array}$ & 0,16 & 0,72 & 0,14 & 0,74 & 3,11 & 0,02 & 0,18 & 0,15 & 1,20 & 0,98 & 1,00 \\
\hline $\begin{array}{l}\text { "Severny } \\
\text { Tekstil" LLC }\end{array}$ & 0,10 & 0,70 & 0,10 & 0,90 & 1,24 & 0,04 & 0,24 & 0,10 & 1,01 & 0,92 & 0,67 \\
\hline $\begin{array}{l}\text { JSC } \\
\text { "Bolshevichka" }\end{array}$ & 0,05 & 0,52 & 0,62 & 0,78 & 2,25 & 0,02 & 0,11 & 0,05 & 0,62 & 0,75 & 0,98 \\
\hline $\begin{array}{l}\text { LLC "Sewing } \\
\text { enterprise } \\
\text { Galant" }\end{array}$ & 0,01 & 0,11 & 0,79 & 0,27 & 2,18 & 0,01 & 0,08 & 0,02 & 0,36 & 0,38 & 0,97 \\
\hline
\end{tabular}

For convenience of calculations, the matrix of source data is standardized as follows: the best value in the column is taken as 1 , the remaining values are divided by the best. The calculation results are shown in table 2:

Table 2. Matrix of standardized indicators characterizing the economic security of the industrial enterprise

\begin{tabular}{|l|c|c|c|c|c|c|c|c|c|c|c|}
\hline \multicolumn{1}{|c|}{ Company } & $\mathbf{X}_{\mathbf{1}}$ & $\mathbf{X}_{\mathbf{2}}$ & $\mathbf{X}_{\mathbf{3}}$ & $\mathbf{X}_{\mathbf{4}}$ & $\mathbf{X}_{\mathbf{5}}$ & $\mathbf{X}_{\mathbf{6}}$ & $\mathbf{X}_{\mathbf{7}}$ & $\mathbf{X}_{\mathbf{8}}$ & $\mathbf{X}_{\mathbf{9}}$ & $\mathbf{X}_{\mathbf{1 0}}$ & $\mathbf{X}_{\mathbf{1 1}}$ \\
\hline CJSC "Salyut" & 0,75 & 1 & 0,19 & 0,67 & 0,34 & 0,75 & 0,96 & 1 & 0,92 & 0,91 & 0,67 \\
\hline $\begin{array}{l}\text { JSC research } \\
\text { and production } \\
\text { enterprise } \\
\text { "ANA" }\end{array}$ & 1 & 0,97 & 0,18 & 0,82 & 1 & 0,50 & 0,75 & 0,75 & 1 & 1 & 1 \\
\hline $\begin{array}{l}\text { "Severny } \\
\text { Tekstil" LLC }\end{array}$ & 0,63 & 0,95 & 0,13 & 1 & 0,40 & 1 & 1 & 0,50 & 0,84 & 0,94 & 0,67 \\
\hline $\begin{array}{l}\text { JSC } \\
\text { "Bolshevichka" }\end{array}$ & 0,31 & 0,70 & 0,78 & 0,87 & 0,72 & 0,50 & 0,46 & 0,25 & 0,52 & 0,77 & 0,98 \\
\hline $\begin{array}{l}\text { LLC "Sewing } \\
\text { enterprise } \\
\text { Galant" }\end{array}$ & 0,06 & 0,15 & 1 & 0,30 & 0,70 & 0,25 & 0,33 & 0,10 & 0,30 & 0,39 & 0,97 \\
\hline
\end{tabular}

Then, according to the method, the values are squared, then the sum of the squares of the values for enterprises is determined, from which the square root is extracted. Based on the results of calculations, the rating of industrial enterprises was determined (table 3).

Table 3. Rating of industrial enterprises by the level of economic security

\begin{tabular}{|c|c|c|c|c|c|c|c|c|c|c|c|c|c|c|}
\hline Company & X1 & $\mathrm{X} 2$ & $\mathbf{X 3}$ & $\mathrm{X} 4$ & X5 & X6 & $\mathbf{X} 7$ & X8 & X9 & $\mathbf{X 1 0}$ & X11 & $\sum$ & $\sqrt{ }$ & 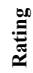 \\
\hline CJSC "Salyut" & 0,56 & 1 & 0,04 & 0,45 & 0,12 & 0,56 & 0,92 & 1 & 0,85 & 0,83 & 0,45 & 6,78 & 2,60 & 2 \\
\hline $\begin{array}{l}\text { JSC research and } \\
\text { production } \\
\text { enterprise "ANA" }\end{array}$ & 1 & 0,94 & 0,03 & 0,67 & 1 & 0,25 & 0,56 & 0,56 & 1 & 1 & 1 & 8,01 & 2,83 & 1 \\
\hline $\begin{array}{l}\text { "Severny Tekstil" } \\
\text { LLC }\end{array}$ & 0,40 & 0,90 & 0,01 & 1 & 0,16 & 1 & 1 & 0,25 & 0,71 & 0,88 & 0,45 & 6,77 & 2,59 & 3 \\
\hline
\end{tabular}

Continuation of Table 3. Rating of industrial enterprises by the level of economic security 


\begin{tabular}{|l|c|c|c|c|c|c|c|c|c|c|c|c|c|c|}
\hline $\begin{array}{l}\text { JSC } \\
\text { "Bolshevichka" }\end{array}$ & 0,10 & 0,49 & 0,61 & 0,76 & 0,52 & 0,25 & 0,21 & 0,06 & 0,27 & 0,59 & 0,96 & 4,82 & 2,20 & 4 \\
\hline $\begin{array}{l}\text { LLC "Sewing } \\
\text { enterprise } \\
\text { Galant" }\end{array}$ & 0 & 0,02 & 1 & 0,09 & 0,49 & 0,06 & 0,11 & 0,01 & 0,09 & 0,15 & 0,94 & 2,96 & 1,72 & 5 \\
\hline
\end{tabular}

Based on the results shown in table 3, the reference ranges of values of integral coefficients for the level of economic security have been determined (table 4).

Table 4.Reference values of the level of economic security of light industry enterprises.

\begin{tabular}{|c|c|}
\hline Level of economic security of enterprises & Range of values \\
\hline 1. High & $2,6-3,0$ \\
\hline 2. Medium & $2,2-2,6$ \\
\hline 3. The risk & $<2,2$ \\
\hline
\end{tabular}

\section{Results and discussions}

The definition of the economic security zone for the studied enterprises is presented in table 5.

Table 5. Zoning of light industry enterprises in accordance with the reference values.

\begin{tabular}{|l|c|c|}
\hline \multicolumn{1}{|c|}{ Enterprise } & Indicator & Zone \\
\hline CJSC "Salyut" & 2,60 & \\
\hline JSC research and production enterprise "ANA" & 2,83 & \\
\hline "Severny Tekstil" LLC & 2,59 & \\
\hline JSC "Bolshevichka" & 2,20 & \\
\hline LLC "Sewing enterprise Galant" & 1,72 & \\
\hline
\end{tabular}

Based on the results of the study, the following conclusions can be drawn:

1. the Leaders in terms of economic security were two companies: CJSC "Salyut" and JSC research and production enterprise "ANA" (high level of economic security of the enterprise).

2. the Average level is reached by: LLC "Severny Tekstil" and JSC "Bolshevichka". These enterprises have the potential to increase the level of economic security to the highest values by eliminating existing problems and shortcomings, as well as by increasing the innovation potential.

3. the company "Sewing Enterprise Galant" was at risk due to its small scale and low level of implementation of innovative technologies.

\section{Conclusions}

It can be concluded that the development of an enterprise in the field of innovation is not only a quick reaction to the application of the latest developments, but also the results of this application, which will directly affect the company's profit and other economic indicators [5].

The ability of an enterprise to quickly implement various types of innovations determines its potential and the possibility of not only maintaining the existing level of economic security, but also its growth in the future. It is very important to stimulate new promising ideas and various kinds of inventions [18].

It should also be noted that monitoring of industrial enterprises by the level of economic security is largely based on the indicators of innovative activity of the enterprise and is of 
particular importance in the prospects for the development of the industry. The more attention the company management pays to the development of the innovation sphere, the more stable is the level of economic security and the more attractive the company is in the eyes of investors. Investment attractiveness is directly related to the allocation of subsidies to the company, which means its further development prospects.

\section{Acknowledgements}

We are very grateful to the organizers of the international scientific and practical conference "Transformation of corporate governance models under the new economic realities" for the opportunity to present and publish a report on topical issues of the impact of new technologies on the development and effectiveness of management systems.

\section{References}

1. E.V. Gorshenin, and N. Chumachenko, Russian entrepreneurship, 63 (2011)

2. E.N. Chizhov, V.Yu. Sorokin, O.O. Vesnina, E.V. Osychenko, Vestnik BSTU named after V. G. Shukhov, 156 (2018)

3. L.M. Putyatin, N.In. Tarasova, L.A. Lavrova, Bulletin Of The University, 49 (2016)

4. E.V Jamai., Y.P. Anisimov, S.A. Povekvechnykh, Finance. Economy. Strategy., 26 (2014)

5. N.In. Alekseeva, T.N. Autograph, O.V. Orlova, Bulletin Of The University, 69 (2018)

6. A.V. Masalov, Ekonominfo, 51 (2007)

7. E. Sapozhnikova, E. Karanina, O. Ryazanova, Svetlana Grin, Revista ESPACIOS, 39 (28), 14 (2018)

8. L. Yurieva, E. Dolzhenkova, E. Karanina, Espacios, 28, 8 (2018)

9. E. Karanina, O. Ryazanova., N. Gritsuk, MATEC Web of Conferences: International Scientific Conference Environmental Science for Construction Industry, 193 (2018)

10. E.V. Karanina, O.A. Ryazanova, A.N. Timin, Advances in Intelligent Systems and Computing : 19th International scientific conference "Energy Managment of Municipal Transportation Facilities and Transport", 318 (2017)

11. E.V. Karanina, O.A. Ryazanova, A.N. Timin, L.P. Domracheva, E3S Web of Conferences 2019, 08002 (2019)

12. G. Snigireva, I. Sennikova, E. Karanina, A. Bakhtimov, L. Domracheva, E3S Web of Conferences 2019, 08063 (2019)

13. E. Karanina, K. Kartavyh, E3S Web of Conferences 2019, 02090 (2019)

14. D. Loginov, E. Karanina, E3S Web of Conferences 2019, 02021 (2019)

15. D.A. Loginov, E.V. Karanina, M.V. Palkina, Growth Poles of the Global Economy: Emergence, Changes and Future Perspectives (2020)

16. E. Karanina, M. Bortnikov, E3S Web of Conferences 164, 10011 (2020)

17. V. Bezdenezhnykh, E. Karanina, D. Arutiunian, E3S Web of Conferences 164, 09009 (2020)

18. Y.A. Vnuchkov, V.A. Moskovsky, E.I. Lukin, Scientific papers (Vestnik MATI), 190 (2011) 